\title{
Family Memories and the Transmission of the Independence Struggle in South Yemen
}

\author{
Anne-Linda Amira Augustin
}

\section{Introduction}

The year 2007 witnessed the birth of the Southern Movement. After the unification between the People's Democratic Republic of Yemen (PDRY) and the Yemen Arab Republic in 1990, power in the state was equally shared across ministries between South and North Yemeni politicians and bureaucrats. The results of the 1993 elections shattered the power-sharing agreement, marginalized the Yemeni Socialist Party (YSP) of the former PDRY, and strengthened the General People's Congress and the Yemeni Congregation for Reform (Ișlāḥ) and, with them, the tribal and Islamist elites of North Yemen. As tensions soared, civil war broke out on April 27, 1994. South Yemeni politicians proclaimed the Democratic Republic of Yemen on May 21, 1994 and, thereby, the disengagement of the territory of the former PDRY from the Republic of Yemen; however, this faction lost this war on July 7, 1994.

Initially, the Southern Movement was a loose coalition. Most of its members consisted of former army personnel and state employees of the PDRY who had been forced from their jobs after the war of $1994 .{ }^{1}$ In 2007, these people began to address their discontent publicly and appealed for socioeconomic rights, such as pensions, or the reinstatement of their former jobs. However, the Yemeni government was unable or unwilling to accede to their appeals. Government security forces used brutal measures against protesters. This government-sponsored brutality and indifference strengthened this loose social movement (see Human

\section{A.-L. A. Augustin ( $\bowtie)$}

Büro der Außenbeziehung des Übergangsrates Südarabiens in Europa e. V., Berlin,

Germany

e-mail: alaugustin@mei.edu

(C) The Author(s) 2021

R. Ouaissa et al. (eds.), Re-Configurations, Politik und Gesellschaft des Nahen

Ostens, https://doi.org/10.1007/978-3-658-31160-5_13 
Rights Watch 2009). More and more people joined the demonstrations, and their appeals began to harden into concrete political demands, such as state independence of the territory that once formed the PDRY.

Since the Southern Movement began in 2007, I have regularly visited Aden and the surrounding governorates to conduct research. From March until May 2014, I conducted a three-month field research for my $\mathrm{PhD}$ dissertation, which was followed by a stay in the field from January to February 2015. Since the outbreak of the war, I have participated in events of the South Yemeni diaspora in Europe. In 2014 and 2015, I conducted participant observations during demonstrations and gatherings of the Southern Movement, as well as interviews with more than 80 people, ranging in age from 19 to around 70, and originating from almost all South Yemeni governorates. I analyzed the interviews via a grounded theory methodological approach as per Strauss and Corbin (1990).

Based on this longstanding field research in South Yemen, this chapter will investigate the role family memories play in the transmission of the independence struggle in South Yemen. Family memories evolve in the interaction between different generations. They imply negotiations and struggles over concepts pertaining to the future of South Yemeni society during times of huge socio-political transformations and political turmoil in Yemen. As I will illustrate in this chapter, family remembrance in South Yemen is a practice of resistance. According to Routledge, "practices of resistance cannot be separated from practices of domination, they are always entangled in some configuration" (1997, p. 70). Thus, family memories are re-configurations that refer to changes in discursive and symbolic power networks. Strikingly, young people have become very active in the Southern Movement, beginning before 2011 but especially once the protests of the "Arab Spring" began in Yemen. During my visits to South Yemen, I often heard young people born after Yemen's 1990 unification saying how great life had been in the PDRY. They often said that "we had" such-and-such accomplishments in the PDRY, that "our state" provided "us" with this or that achievement. Thus, they strongly identified with a state that had disappeared from the world map two decades earlier, before they were even born. Where did their longing for the PDRY come from? And how could claims of an independent state in South Yemen reemerge in 2007 after the previous attempts at independence were dismantled in 1994?

Using interview extracts and participant observations from my field research, I will give insight into the enormous impact of family memories on young people's longing for the PDRY, and, therefore, on their political engagement for an independent state in South Yemen. 


\section{The Role of Family Memories in Contexts of Defeats}

The family, a network of individuals comprised of two or more biological generations related by kinship, is "the main channel for the transmission of language, names, land and housing, local social standing, and religion; and beyond that also of social values and aspirations, fears, world views, domestic skills, taken-for-granted ways of behaving, attitudes to the body, models of parenting and marriage" (Bertaux and Thompson 1993, p. 1 f.). Besides school and media, the family "is the foremost mnemonic community, as it teaches children how to recall their past in a structured and socially acceptable manner" (Ryan 2011, p. 156). Memories never exist as closed systems, however. They touch, strengthen, intersect with, modify, and polarize other memories in the social reality (Assmann 2006, p. 17). Thus, an individual's memory is always comprised of both individual and collective memories (Assmann 2006, p. 23) and socially supported, constructed, and stabilized by communication with other people (Assmann 2006, p. 25). Family memories are "social memories" (Welzer 2001) that involve intentional forms of communication and transmission but also unnoticed, unintentional, and incidental transmissions of history (Welzer 2001, p. 16 f.).

I remember my own relatives, neighbors, and friends in South Yemen transmitting to me the nostalgia that everything had been better in the past; that people had been united in the independence struggle against the British in the 1960s; that people had celebrated New Year's Eve before unification; that people were well educated and knew the writings of Marx, Lenin, and Hugo; that education was much better by far than nowadays; that Aden had been a clean city with electricity and running water; that not everything was forbidden (harām) or a source of shame ( $a y b)$ as it had become; that unveiled women could go out in the streets without being harassed; that there had been an atmosphere of mutual respect, particularly towards women; that all children attended school, etc. Such pronouncements are often interwoven in everyday communication without any specific intentions. These counter-memories link to the narration of a better past, a current difficult present, and a desirable better future. The belief in a better future, that would be at least as good as the past, is an important trigger for the claims of reestablishing an independent state on the territory of the former PDRY. This belief is firmly linked to the South's defeat in the 1994 war and to the subsequent marginalization of the South Yemeni population in its aftermath.

According to the unity narrative of the Republic of Yemen, which is omnipresent in Yemeni textbooks, unification was the sole source of progress, advancement, and development for the entire country. Most people in South Yemen 
perceived the opposite to be true. The obstacles to unity in 1990, the brutality of the war in 1994, and the massive marginalization of South Yemenis after this war was silenced from national official history, such as from nationalized textbooks, museums, political speeches and documents, etc. Therefore, the national narrative of the Republic of Yemen contradicts the many-voiced social memories in South Yemen. According to Argenti and Schramm (2010), a hegemonic narrative is often created when a violent past becomes the foundation for building a common future. In this process, the hegemonic narrative "first cuts out everything that does not fit into the dominant story-line (of victimization, heroism etc.) and secondly puts the past at a somewhat comfortable distance from the present" (Argenti and Schramm 2010, p. 18). Nevertheless, "[i]ndividual memories are not easily overwritten and family stories are often preserved across generations through oral transmission" (Assmann and Shortt 2012, p. 4). As Yemeni unification in 1990 and the war of 1994 are the primary events in South Yemeni remembrance, based on which historical experiences are (re)interpreted and construed, family memories are incompatible with the official narrative that has been constructed in the aftermath of the war in 1994.

The unity narrative, which became dominant in education, political speeches, and public life after the war of 1994, clashed with South Yemeni memories because South Yemenis have underlined marginalized elements of their collective memory and created new interpretations of the past countering the unity narrative. These South Yemeni counter-memories challenge official versions of the past and emphasize South Yemenis' suppressed experiences. This "mnemonic resistance" (Ryan 2011, p. 155), "the resistance to a collective memory narrative" (Ryan 2011, p. 159), refers to South Yemenis' interpretative agency to resist "the encroachments of a powerful dominant memory" (Ryan 2011, p. 155). As political and/or state institutions that allowed a remembrance of South Yemeni representations of the past were non-existent after the war in 1994, due to the defeat of the South Yemeni faction and the flight of South Yemeni elites, the South Yemeni population took over the task of remembering in accordance with their representations of the past in daily communication and get-togethers.

However, the rupture that generated counter-memories on a collective level in South Yemen emanates from more than experiences of the war in 1994. It also, particularly, stems from the subsequent large-scale marginalization of South Yemenis. Most of the activists of the Southern Movement whom I met during my field research were either forcibly retired or had a relative (often a parent) who had been forced into retirement after the war. Thus, there is a connection between the forced retirees and political mobilization in South Yemen. Under certain conditions, defeats can become central historical reference points; defeats are remem- 
bered, not only victories (Assmann 2006, p. 64). The memory of the losing side of the violent conflict can have a stronger impact than the same conflict has of the victors. Defeats do not necessarily destroy people's collective self-perception; they can also strengthen a group's cohesion. In cases in which a community's identity is based on a consciousness of victimhood, for example, the memory of suffering is borne in remembrance: this encourages community cohesion and mobilizes opposition. In this respect, defeats may strengthen the will for national autonomy and/or independence from a hegemonic power (Assmann 2006, p. $65 \mathrm{f}$.). In the following, I will illustrate how family memories transmitted the desire for an independent state to young South Yemenis who grew up after Yemeni unification.

\section{The Transmission of Independence in Families}

In answer to my question about why young South Yemenis want to reestablish a state that they have never experienced, a man at a qāt-chewing gathering explained that the Arab family structure has a strong cohesive influence on its members:

Arab society is different. Family ties in Yemen differ from those in Europe. In Yemen, in the south [South Yemen] or Arab countries, relations between father, son, and grandfather exist inside the family. The son absorbs the ideas that his father and grandfather have. They live together for a long time because they do not separate so much. He does not distance himself from them. That is why they transmit everything they carry to him.[...] The youth are influenced by the past, and they know that it was better than the present. This stems from the family relationships-because I explain to my son, and my father explains to my son how he lived in the past, and how I lived. ${ }^{2}$

The older generations pass on to the young the nostalgic representations of their earlier lives, and the young absorb the ideas of their fathers and grandfathers. However, this is a very static notion of intergenerational transmission from the older to the younger generation and from men to other men. Daily communication in South Yemeni families involves counter-memories disseminated and dialogically transmitted in "conversational remembering" (Welzer 2010), in which representations of the South Yemeni past are invoked and collaboratively reconstructed.

In many instances where youth have mobilized, their knowledge about the former PDRY and the independence struggle began with family memories: ${ }^{3}$ 
A person-no matter how young — can become impressed by relatives, by uncles, by writers, journalists, academics, intellectuals, and party leaders. Concerning my surroundings, my family and relatives have relations to the revolution, to politics. My paternal uncle was secretary general of the party during a certain period. My paternal uncles were YSP leaders in the 1980s and in the 1970s. Thus, ideas of rejection, of revolution, and of many ideas developed in me. The emergence of the Southern Movement influenced the minds of all people and contributed to the development of a certain direction and mindset. ... We feel that our economic problems take place on a family level. There is no health care, no quality education, no services provided by the state. The right to state employment is impossible in Yemen; you pay money for a mediator. All these things, this suffering, concern the people. ${ }^{4}$

Țāriq comes from a family of YSP politicians. He explained that these relatives and others, such as "writers, journalists, academics, intellectuals, and party leaders," impressed him, which led to his interest in the grievances and claims of South Yemenis and finally made him politically active. His sources of knowledge vary; however, his politically active family played the largest role in influencing him via transmission. Tāriq's example demonstrates a strong connection between a family's political orientation and that of its descendants. Nevertheless, active Southern Movement parents do not automatically have active Southern Movement children, and vice versa. The situation in which people were living also made him aware of the grievances in South Yemen and the claims of the Southern Movement. Hence, "[t]he emergence of the Southern Movement influenced the minds of all people and contributed to the development of a certain direction and mindset," as Țāriq expressed in the interview quoted above. Although not all South Yemeni families have been engaged in political parties in recent years, their children can still be politically active, as the following example demonstrates:

My father, my mother, the people, books; all those who speak [gave information about the past]. It would be wrong to tell you that only the house, my mother, I and so on speak; rather, all people speak. You read books, news. Everywhere you feel it. You speak to someone, and he tells you "We were, we were, we were. I worked in this and now I am sitting [jālis] at home. In the past, I traveled; today I do not have anything." ${ }^{5}$

Using a direct quotation, this female activist pointed out that South Yemeni forced retirees-known as jālisīn, ${ }^{6}$ meaning "those who sit at home"- have an impact on young people because they disseminate in conversation their feelings of marginalization and exclusion. The forced retirees thus symbolize South Yemenis' exclusion from development and embody the lack of improvement and opportunity in the region. Forced retirees were among the first protesters in 
2007 and used collective action to show their discontent. However, long before the emergence of the Southern Movement, they were already numerous, and their forced retirement reminded their families, friends, and neighbors that the war in 1994 had been lost by the South Yemeni faction. People have felt punished, unjustly treated, and betrayed by the elites of North Yemen.

The following examples illustrate the connection between the forced retirees and their impact on family memories, as well as on political mobilization in South Yemen. A young man in his late twenties recounted that his father had been a soldier. After the war in 1994, he was forced to retire from his post. In 2014, he sometimes received a monthly pension of 30,000 Yemeni riyāl (around $100 €$ or 140 US\$). The young man complained that a North Yemeni would receive three times as much as his father. Because of the inadequate income, his father lost the family's house. After telling me the story of his father, the young man then asked me rhetorically how he could support unification in light of the injustice done to his father.

A woman in her early thirties reported that her mother lost her job and was forced to stay at home soon after the war in 1994. During the war, a North Yemeni pilot had seized the family's flat in Aden. With legal documents proving their ownership, they were able to regain the flat by taking their case to court. The young woman is also an activist today. Thus, the basis of the Southern Movement comprised not only the forced retirees, but also their children, whose parents and relatives symbolized for them the injustice promoted by the central government in Sanaa. In these cases, it is not necessary for intergenerational transmission to occur as a speech act: parental unemployment, a family's lack of money, and social insecurities transmitted the families' marginalization to the next generation without the need for words.

Once, I was sitting in the Aden Mall and speaking to young activists when a forcibly retired army general heard us talking and approached us. He began narrating his experiences of marginalization after the war in 1994 and his long struggle to be re-employed. He also told me that about the frustration and stress of not being able to support the family. While listening to us, he felt resentment about what had happened to him in the past, and he began narrating, thereby giving us - the younger generation-ideas about his life and the negative consequences of Yemeni unification and the subsequent war. He transmitted representations of the past, encouraged to speak by the communication between the young activists and me about today's independence struggle. Such narrations take place not only in interview situations, but also during everyday communication among families, on the streets, and in neighborhoods in South Yemen; people talk about perceived injustices, and, by doing so, they transmit their longing for the PDRY and their 
desire to reestablish an independent state. This example shows that the intergenerational transmission of the independence struggle is not unidirectional from older to younger generations only, but is in fact a dialogical process in which both generations interact to construct a social memory, a process in which the past and current situation is reinterpreted and construed. The following statement also exemplifies this dialogical relationship:

The leaders of the generation of our fathers and grandfathers wrote history for us and wrote novels for us about what happened, what happened before the war in 1994 and before the signing of the unity [treaty], and during the war [in 1994] and how the transformation happened.... We are born during the phase of Yemeni unification. To this day, our school curriculum has not mentioned the PDRY but its relics still exist with us. ... We learn from our fathers and grandfathers, and now we are transferring to the world [the knowledge] that marginalization happened here. ${ }^{7}$

Nadīm points out that leading figures of his father's and grandfather's generation wrote down the events of the past, those that occurred during the war in 1994 and during the unity agreements. He also points out that young South Yemenis are now transmitting knowledge that was once transferred by the fathers' and grandfathers' generations. This dialogical transmission led to the young now becoming the ones narrating to "the world that marginalization happened" in South Yemen. Hence, the dissemination of memories among family members influences young people's political engagement for an independent state.

Another extract from a group discussion with university students in Aden in April 2014 indicates similarly that family memories in South Yemen are important for understanding young people's mobilization for independence:

Man 1: Every family fears for their sons, but they do not prevent you from carrying out your activities. They advise you to be careful; they fear for you. They call you, but they do not prevent your activities. The same goes for my mother. She sees her children in this situation. She does not accept this situation. My father does not accept it either. My brother, my sister, the entire house, do not accept this situation. They reject this situation. Thus, they allow you [to go to demonstrations etc.], but they fear for you with all certainty.

Man 2: Our activities [in the streets/during protests/in university] are not hanging around or something like this. Rather, it is a reality of tyranny that we suffer from. Our future is gone. Our country is gone. We have to do something. We are forced to do this, of course, to reject tyranny. 
Man 3: The sacrifice for it, it is a duty. We have to make sacrifices when we are active.[...] This reality requires sacrifices. This is compulsory. These are my inner feelings. This matter is compulsory, whether the family consents or not.

Man 1: Some families prevent you, but their sons reject that.

Man 2: Many families.

Man 1: Some sons do not inform their families. They go secretly [to protests etc.] without telling them.

Man 2: There are even young people who are silent, but not in the sense that they accept the reality. However, the degree of anxiety differs from person to person. It is the issue of rejecting reality or changing reality. Sacrifice for the purpose of reality. ${ }^{8}$

This discussion indicates that the transmission of the independence struggle is a two-sided coin. On the one hand, families do "not accept this situation," i.e. "tyranny", suffering, marginalization, unemployment, and the ramifications of Yemeni unification in general. Therefore, dissatisfied with the situation, families have transmitted to younger generations their discontent with their life circumstances and their wish to regain an independent state on the territory of the PDRY. On the other hand, families, especially those who are not politically active, are uneasy with or even reject their children's participation in protests because they fear they could lose their children. However, according to my interview partner, it is "compulsory," "a duty" to "make sacrifices" for the future and the country. They feel "forced" to act, and their anxious families have to accept this. The independence struggle becomes a duty, an obligation, for a better future.

\section{Conclusion}

By nostalgically lamenting the PDRY past in daily conversations, older generations who lived in the PDRY have transmitted their wish to recreate a South Yemeni state to younger generations. The Southern Movement has begun to contest the unity narrative of the Republic of Yemen publicly since 2007. However, as the extracts and examples in this chapter indicate, the struggle for an independent state had already begun long before the Southern Movement emerged in 2007. In particular, South Yemeni involuntary retirees, who were affected by largescale marginalization after the war in 1994, had an enormous impact on transmitting counter-memories to younger generations, and, thus, on South Yemeni 
society and its claims to reestablish the state on the territory of the former PDRY. These people became the basis of the Southern Movement in 2007, which soon transformed from a social movement appealing economic and social rights into an independence movement demanding the reestablishment of an independent state. Thus, family memories play a crucial role in the transmission of the independence struggle in South Yemen, and particularly in the dissemination of the longing for the PDRY to young people and the hope that only independence can bring back a stable and safe life. Young people, who never experienced life in the PDRY because they were born only after Yemeni unification, have received knowledge about the past from their elders. However, the elders' transmission is not a static process from the older to the younger generation, but a dialogical process in which the young engage with the older generations' remembrance. Thus, young people's political engagement for an independent state in South Yemen is linked to family memories, which involve the transmission of counter-memories that challenge the unity narrative of the Republic of Yemen.

\section{Endnotes}

1. Thousands of South Yemenis were affected by forced retirement. See Kambeck (2016), for statistics on those forcibly retired after the war.

2. Personal interview with a man at a qāt gathering in Aden, March 2014.

3. Some interview partners, all of them originating from al-Dali', told me that their consciousness of politics and the southern cause can be traced back to their own traumatic childhood experiences during the war of 1994. However, due to the geographical closeness to North Yemen, the war in 1994 could have been more intensive and more violent there than in other areas.

4. Personal interview with Țāriq (pseudonym) in Aden, January 2015.

5. Personal interview with Samīra (pseudonym) in Aden, January 2015

6. Jälis is an Arabic term used to designate forced retirees colloquially in South Yemen.

7. Personal interview with Nadīm (pseudonym) in Aden, March 2014.

8. Personal interviews (group discussion) in Aden, April 2014.

\section{References}

Argenti, N., and K. Schramm. 2010. Introduction: Remembering violence: Anthropological perspectives on intergenerational transmission. In Remembering violence: Anthropological perspectives on intergenerational transmission, ed. N. Argenti and K. Schramm, 1-39. Oxford: Berghahn. 
Assmann, Aleida. 2006. Der lange Schatten der Vergangenheit. Erinnerungskultur und Geschichtspolitik [The Long Shadow of the Past. Commemorative Culture and Politics of History]. München: Beck.

Assmann, A., and L. Shortt. 2012. Memory and political change: Introduction. In Memory and political change, ed. A. Assmann and L. Shortt, 1-14. Basingstoke: Palgrave Macmillan.

Bertaux, D., and P. Thompson. 1993. Introduction. In Between generations: Family models, myths \& memories, ed. D. Bertaux and P. Thompson, 1-12. Oxford: Oxford University Press.

Human Rights Watch. 2009. In the name of unity: The Yemeni government's brutal response to southern movement protests. New York: Human Rights Watch.

Kambeck, J. 2016. Returning to transitional justice in Yemen. A backgrounder on the commission on the forcibly retired in the Southern Governorates. CARPO Report 3.

Routledge, Paul. 1997. A spatiality of resistance: Theory and practice in Nepal's Revolution of 1990. In Geographies of resistance, ed. S. Pile and M. Keith, 68-86. London: Routledge.

Ryan, L. 2011. Memory, power and resistance: The anatomy of a tripartite relationship. Memory Studies 4 (2): 154-169.

Strauss, Anselm, and J. Corbin. 1990. Basics of qualitative research. Grounded theory procedures and techniques. Newbury Park, CA: Sage.

Welzer, H. 2001. Das soziale Gedächtnis [The Social Memory]. In Das Soziale Gedächtnis: Geschichte, Erinnerung, Tradierung [The Social Memory: History, Memory, Transmission], ed. Harald Welzer, 9-21. Hamburg: Hamburger Edition.

Welzer, H. 2010. Re-narrations: How pasts change in conversational remembering. Memory Studies 3 (5): 5-17.

Anne-Linda Amira Augustin did her doctorate in sociology on the Southern Movement, resistance, and generational relations in South Yemen in the research network "Re-Configurations" at the Philipps-Universität Marburg (Germany). She is a non-resident scholar at the Middle East Institute in Washington. She is currently working as an advisor at the European representative office of the Southern Transitional Council in Berlin. 
Open Access This chapter is licensed under the terms of the Creative Commons Attribution 4.0 International License (http://creativecommons.org/licenses/by/4.0/), which permits use, sharing, adaptation, distribution and reproduction in any medium or format, as long as you give appropriate credit to the original author(s) and the source, provide a link to the Creative Commons license and indicate if changes were made.

The images or other third party material in this chapter are included in the chapter's Creative Commons license, unless indicated otherwise in a credit line to the material. If material is not included in the chapter's Creative Commons license and your intended use is not permitted by statutory regulation or exceeds the permitted use, you will need to obtain permission directly from the copyright holder. 